\title{
The Moderat Role Of Knowledge Sharing On The Effect Of Human Capital In Job Empowerment
}

\author{
Abdallah Mishael Obeidat, Business Administration Department-Business Collage- Jadara University-Jordan. \\ aabdullahh2000@hotmail.comU29T \\ Hazem atef wahiby, Business Administration Department -Business Collage-Jadara University-Jordan. \\ Dua'a mohammad alshammari, Business Administration Department -Business Collage- Jadara University- \\ Jordan. \\ Sara khaled alzu'bi, Business Administration Department -Business Collage-Jadara University-Jordan. \\ Ahmad fathe hadrab, Business Administration Department -Business Collage-Jadara University-Jordan. \\ Mohamad ali samara, Business Administration Department -Business Collage-Jadara University-Jordan.
}

\begin{abstract}
This study is aimed at identifying the modified role of knowledge sharing in the relationship between human capital and job empowerment at Jadara University. To achieve the aim of the study, the researchers used the descriptive and analytical approach, where they designed a questionnaire that includes the study variables, and distributed it to the university's administrative workers. The appropriate statistical methods were used for its analysis. Accordingly, the study found out that there is a statistically significant effect of knowledge sharing on the relationship between human capital and empowerment at Jadara University.
\end{abstract}

Keywords: knowledge sharing, human capital job empowerment, Jadara University m jordan

$\begin{array}{lll}\text { Received: 06.12.2020 } & \text { Accepted: 13.01.2021 } & \text { Published: 03.02.2021 }\end{array}$

\section{INTRODUCTION}

The scientific studies have begun to direct attention to empowering practices in increasing workers' production, organizational commitment, job satisfaction, and increasing innovative capabilities (Fernandez \& Moldogaziev, 2011). This means the individual's perception or feeling that he has an influence on the decisions taken along with the policies set up by the organizations, and in particular those related to his work. Such perception or feeling doesn't come except if the individual has and effect or controls matters of little importance in his work, but it shall be formed and grown if the individual has an influence in important matters that contribute to the achievement of the goals of the organization, which, hence, increases the internal motivation of the individual, such motivation is stemming from the job itself (Herzberg, 2013). Consequently, the researchers have cited several dimensions of empowerment; HenkinK (2011) believes that empowerment consists of influence, competence, choice, and the meaning of work. Meanwhile, Spector (2011) considered empowerment in two dimensions, the skill dimension, that is, providing workers with the skills of teamwork, and the second dimension, which is the administrative dimension; i. e. giving freedom and authority to make decisions for all members of the organization. One of the important features of the empowered organization is the top management focus on the development of people in the organization, create vision and inspire Joint objectives, environment analysis and continuous adaptation to it, focus on teamwork and collaborative work, along with the availability of a flexible organizational structure that develops over time, and promotes a sense of responsibility and skills development, employees' sense of personal responsibility, direct decision-making in relation to their work, job enrichment through training, skill development and access to information (Honold, 2011).

Therefore, knowledge is power, and it is the most valuable resource of the organization. (Druker 1993) indicated that knowledge has been considered as the main resource instead of being one of the organization's resources (Crawford, 2011, p2). Hence, the organizations should pay attention to it and try to ensure the existence of knowledge. Consequently, sharing this knowledge between the employees among themselves, or between the employees and customers, is the way to achieve the success of the organization, especially as the future of the organization depends on better knowledge. It is necessary for the organization to make sure that 
it has knowledge, since as knowledge sharing is the most important component of knowledge management (Akamavi et al, 2011, p76). In addition, knowledge sharing also achieves competitive advantages by improving the organization's ability to satisfy the diverse needs of the customer, and respond to rapid changes in demand ( Cheng \& Chen, 2012); and within the context of a knowledge-based economy, the importance of material resources has shifted to knowledge resources (Ozbebek \& Toplu, 2011).

It is worth noting that the human capital theory is related to the perspective that directs the company's resources, and according to this view, the continuous competitive advantage is achieved when the company has human resources that cannot be imitated or replaced by its competitors in the market (Buta, 2015), by providing workers to fill skilled vacancies, attracting specialized talent to enable innovation, or achieving 'cost effectiveness' which are key goals of the organizational recruitment strategies from a theoretical human capital perspective (Coff \& Kryscynski, 2011;Delery and Roumpi, 2017; Aljawarneh et al, 2020). Furthermore, human capital theory is mainly concerned with skills and other valuable traits of workers (Ployhart, 2006).

This study is aimed at identifying the modified role of knowledge-sharing in the relationship between human capital and empowerment among administrative workers at Jadara University, and despite Jadara University's endeavor to prepare the organizational climate that motivates workers to develop their performance through sharing knowledge and experiences among employees, the organizational culture in the private higher education sector in Jordan has not yet risen to the level of reliance on workers and giving them sufficient powers to take decisions and empower them. Hence, this study is meant to identifying the role of knowledge sharing and practiced by workers in the possibility of increasing their job arbitration.

\section{LITERATURE REVIEW HUMAN CAPITAL}

Human capital is referred to as the experiences, knowledge, skills and abilities that individuals possess and use in production processes, which can be measured through training and development incentive system (Fitzenz 2000, 2000). "It also represents the energies, enthusiasm, creativity and qualities that the workers in the organization possess and invest them in work, which contributes to building a person physically, mentally and skillfully from his childhood until reaching the age of work and includes spending on health, nutrition, training and education (Al-Tanboor, 2007), a mental strength sourced from knowledge, information, intelligence and experience, and affects the increase in the market, operational and development value of the organization, 2003 "Malhorta"). However, and due to the importance of human capital, there is an agreement that the challenges that the new element in any organization bears will only be addressed by human capital because it is constantly advancing, constantly growing, whether at the individual level or at the level of societies, where the human capital system includes recognition of the number of workers required and their skills, especially those with knowledge through knowledge sharing. (Retribution, 2008).

Therefore, human capital plays an important role in serving economic and social development in all countries of the world, especially as human capital is the most important resource for organizations in the wake of the global trend towards globalization, which requires a quantitative and qualitative accumulation in human capital (Obeidat et al, 2018), due to the rare characteristics, especially its rarity and the difficulty of simulation or imitating it by competitors, which pushes the organization to monopolize it in comparison to other organizations. It is worth stating that the interest in human capital has increased, as a result of its great role in the organization, which works to presenting new ideas innovations and inventions that contribute to enhancing the ability of the organizations to respond to the changes that occur in their external environment, which, hence, increases their ability to respond quickly to the requirements of their customers. (Shabir, 2015) The human capital is considered as one of the most important components of intellectual capital, and the decisive factor in the successes achieved by the organization in all its varieties, and the most important resource in finding its strategic competitive advantage as well as its added value. It is, also, the basis for the existence of its capital, which is the organizational structure, and determining its value, i. e. the most important element for creativity, innovation and strategic renewal. Besides, it is also an important factor in the development, and, therefore, knowledge-based organizations put before them a strategic goal, which is represented by developing the competencies and qualities of their human capital and invest in it. Furthermore, it can be said that the most valuable type of the capital is what is invested in people, because human capital has a feature that is not available in other than human himself, where his productivity curve rises along with the curve of his experiences and the same skills, and that his intangible life is renewed with the changes of time, and, will not disappear except with the cessation of his chronological life. (Hamshari, 2013). Therefore, the importance of human capital becomes evident through its effective role in the life of the 
organizations, as being one of the most important elements in the productive process. It also helps to innovate and create and achieve its competitive advantage. In light of technological progress, which reduces the jobs that need knowledge and is represented by a mixture of experience, perception, skill, values and information, meanings and Jaradat have indicated (Ma'ani \& Jaradat, 2010).

\section{EMPOWERMENT}

Empowerment is defined as the process by which managers help employees acquire the skills and authority they need to make decisions that affect them and their work (Schermerhorn et al, 2001). Morhead \& Griffin (2014) expressed it in the process of workers who are setting the goals for their work, making decisions and solving problems within their responsibility and independence. Meanwhile, from the viewpoint of (Al-Ha'ar 2016), empowerment depends greatly on the mutual trust between the leadership in the organization and the employees. In addition, Sternberg (2004) indicated that it increases the motivation of workers at work by delegating authority to the lower levels of the organization.

As a result, the concept of empowerment in management thought came to demand the abandonment of the traditional model of leadership, which focuses on directing to leadership that believes in participation and consultation to increase the benefit of working individuals. This in turn requires a radical change in work roles (Maani et al., 2011) by increasing the area of their participation in the process of making decisions and enhancing their effectiveness in a way that is reflected in the performance of the organization (Al-Naama and Suleiman, 2012). On these basis, the human resources department in the organization has the task of empowering success as the entity responsible for managing performance, training, designing jobs and determining wages, as managers must be trained to be the link between workers and other resources inside and outside the organization (AL-Hajr \& Obeidat, 2019)), and assisting workers in interacting with each other at all levels of the organization, as well as ensuring that these workers keep abreast of important issues that may arise, including training them on the communication tools and gathering information (Al-Husseini and Jalib, 2013).

Job empowerment is aimed at making the organization more capable of responding to the changing environment and more appreciative to support innovation. In addition, it also allows job empowerment to create and finding functional integration between the employees. Besides, it helps job empowerment to contribute and participate in decision-making, in addition to effectively bearing the risks of their work, and it helps workers also to solve the problems they face by relying on knowledge sharing between them along with the exchange of experiences without waiting for their solution to be resolved by their superiors. Bowen and Lawler 1995), especially as job empowerment in any organization is related to risk, flexibility and persuasion ability, in addition to using the scientific method for thinking and solving problems that represent the most prominent creative behaviors of workers. In addition, the empowered workers are more able to explain the necessary processes to accomplish any work and search for creative solutions to work problems that occur in any organization. (Kirkman, 2004). Moreover, job empowerment is also considered as a measurement tool by which the organizations' behavior is measured about its productivity, where the productivity of employees is better when they are authorized by the management in the decision-making methodology in participation with the superiors. Also, job empowerment of employees works to develop morale and commitment, in addition to encouraging innovation, creativity, sharing knowledge, and instilling common values to provide an appropriate environment for learning and achievement. (2009, Carter) On the other side and from the viewpoint of Moke (2015), the importance of empowerment in the job environment is reflected in two directions, the first is communication, and that is through the organization of communication between the employees in the organization, and the second direction represented by motivation; and that is by providing all kinds of incentives that affect the individual's desire to empower. Accordingly, the researcher believes that administrative empowerment leads to a creative effect that leads to institutional excellence at all levels. Therefore, administrative empowerment is the main support for the competition of the educational organization.

\section{KNOWLEDGE SHARING}

Bartol \& Srivastava (2002) indicates that knowledge sharing is the exchange or sharing of information, ideas, suggestions, and experiences related to the organization with each other, this includes exchange of explicit as well as implicit knowledge sharing. Hence, knowledge sharing is a process that takes place between the individuals who share a common goal or common interests or face similar problems, which is not limited to the exchange of explicit or declared knowledge, but also includes the sharing of implicit hidden knowledge 
inherent in the human minds, especially as knowledge sharing expresses an activity for the flow of knowledge from a person who has it to another person or group needs it in a way that can be understood and used (Obeidat, 2019). It is also a voluntary work, not compulsory, and it is difficult to force members to do so. Therefore, the process of knowledge cognitive sharing is a dynamic process where individuals learn and interact continuously to achieve creativity and innovation. (Abdel Hafez and Al Mahdi, 2015).

Furthermore, knowledge sharing is considered as an essential component of knowledge management and a pivotal process within its operations, which also includes knowledge acquisition, storage, application and evaluation, as there are activities of transferring or disseminating knowledge from one person to another or from one group or institution to another. This includes the exchange of implicit and explicit knowledge alike. (Lee, 2001).

Therefore, knowledge-sharing process takes multiple forms that can be achieved without relying on the presence of technology in some situations, such as direct contact that occurs between the individuals in conferences, meetings, training workshops, dialogue sessions, exchange of views, and the method of selfevaluation questionnaires (Obeidat \& Otibi, 2015), as these methods of communication enable access to the implicit tacit knowledge which is present in the minds of individuals, and facilitate their sharing and benefit from it. This, of course, enhances the importance of the human factor in the success of knowledge management and its sharing alongside technology, as information and technology represent little value if you do not find someone to manage it efficiently. As a result, technology plays the role of a catalyst that enables and facilitates the process of knowledge sharing through the internet, as it is a means that improves the mechanism of information exchange, dissemination and sharing of knowledge, supports cooperation and interdependence between the parts of the organization, increases the effectiveness of coordination and access to information better and faster, and facilitates the practice of mental storming operations, and the exchange of electronic dialogues and discussions inside and outside the organization. (Hassan, 2008).

Accordingly, knowledge sharing is aimed at developing the individual's career path through: gaining a professional reputation and recognition within the organization, as a result of sharing his knowledge with others; utilizing the knowledge of others in improving performance (Saffar \& Obeidat, 2020). (Chau et al, 2003) believes that sharing knowledge aims at both activating the sharing of areas of expertise between the customer and work teams, identifying the needs of the software systems in the organization, and attracting new knowledge from the team members, gathering the knowledge held by the distributed individuals to form a repository of organizational knowledge, preserving knowledge that could be lost by the exit of employees with diverse experiences, and improving dissemination of organizational knowledge.

\section{RESEARCH METHODOLOGY HYPOTHESIS DEVELOPMENT}

Job empowerment is one considered as one of the components of the success of organizations and distinguishes them from each other, as it is the driving force for the patterns of behavior of workers, as it works to strengthen the human capital in the organization, and, here, in turn, the empowerment is reflected in the satisfaction and productivity of these workers, and, then, the organization shall be reaching the stage of development and creativity when it worked on the merging between job empowerment and human capital through the availability of human competencies that possess knowledge and competencies and the sharing of this knowledge among the workers of the organization which, then, ensure the organization's continuity of its work and its survival. (Al-Tamimi, 2004). Therefore, the relationship between job empowerment and human capital stems from the reciprocal relationship between them, as the workers' perception of the organization that they are linked to it by a single organizational coordinate resulting from the behavior of the management with the workers and their interaction with the management. This relationship shall be open in terms of the field of job empowerment in most levels of the organizational structure of the organization and from the knowledge participation among the employees along with their participation in the decision-making process, and finally, job empowerment increases the employee's loyalty to the organization. (Al-Sijari, 2012). As a result, empowerment is considered as a rich concept that ranges from granting the authority and independence to decision-making to employees, to providing strategic resources to employees, and organizational knowledge - which is a strategic resource for the organization - and, at the end, enhances the empowerment of employees. When the employees share knowledge frequently, communication increases, which leads to the development of mutual relationships and strong social bonds. Also, this helps employees to understand how the organization works (Afsar et al., 2017 et al., 2020 Tripathi). Therefore, the organizations adopt the concept of career empowerment that depends mainly on sharing the knowledge of workers 
through their sharing of knowledge, relationships and communication channels, in addition to worker's participation with the administration in decision-making, as the human element in the organization is the way to compete (Al-Rumaihi, 2011). Thus, the employees' possession of knowledge in all its aspects is an important and fundamental factor in the success of the empowerment process (Daft 2001).

The relationship between knowledge management processes and human capital lies in the positive interdependence between them and this can be shown through the importance and role that knowledge management processes play by relying on the dimensions of human capital in terms of skills, expertise and knowledge. So, identifying knowledge requires experience to implement work tasks and acquire, collect and extract knowledge from the experts who possess appropriate knowledge (Al-Zahir, 2009; shrouf et al, 2020), especially as knowledge in itself requires a combination of ability, experience, knowledge, information and data (Hegazy, 2005; Al-qudah et al, 2020). Accordingly, the organization focuses on individuals with experience, skill and evaluation of their actual performance in order to be able to implement knowledge management processes and reach the underlined goal (Derry and Kiswani, 2009; Mahfodh \& Obeidat, 2020). Based on the above, the study assumes the following:

H1: Human capital positively affects empowerment

H2: Knowledge sharing positively moderates the relationship between human capitals on empowerment

\section{STUDY TOOL}

The researcher designed a questionnaire consisting of two parts:

Part One: This part contains the demographic data of the respondents, which are: gender, academic qualification, job title, years of experience, and

Part Two: This part includes three variables which are human capital, job empowerment, and knowledge sharing.

The questionnaire used the measurement method based on the five Likert scale to determine the weights of the paragraphs assigned to measure each variable of the study, and to determine the general level of the variable, which represents strongly agree (5) to strongly disagree (1) attached to Annex No. (1). The apparent validity of the questionnaire was tested by presenting it to a panel of experienced and competent arbitrators from academic professors, in order to express an opinion regarding it in terms of its suitability for collecting data related to the study, its clarity, coherence and cohesion, or any other remarks that they deem appropriate regarding the correction or deletion and as deemed appropriate by the arbitrators. The comments of the arbitrators and their suggestions were taken into consideration, and the process of reviewing and auditing the questionnaire by the arbitrators, taking their observations and suggestions, in addition to making the modifications referred to by them was a test for the apparent validity of the tool, and, accordingly, the study tool is considered valid for measuring what it was designed for, exactly as was done. In addition, the test for the reliability of the instrument used in measuring the variables that it contained using the Cronbach Alpha Coefficient Test, where the result of the scale is statistically acceptable if the value of Cronbach Alpha is greater than (0.70) (Sekaran, 2006, 311). Also, the closer the value to (100\%), this indicate a higher stability scores for the study tool. Thus, by looking at the data presented in the following table, Cronbach alpha internal consistency coefficient was measured for the study variables and for its dimensions and for the study tool as a whole so as to find out the consistency in the answers which came as follows:

Table (1): The values of the internal consistency coefficient for the study tool items

\begin{tabular}{lll}
\hline No. & Dimension & Alpha value \\
\hline $\mathbf{1}$ & Human capital & 0.859 \\
$\mathbf{2}$ & Empowerment & 0.916 \\
3 & Knowledge sharing & 0.934 \\
Study tool & $\mathbf{0 . 9 1 2}$ \\
\hline
\end{tabular}

It is quite evident from the results of Table (1) that the values of the internal consistency coefficient of Cronbach Alpha for the paragraphs of the study tool ranged between (0.859-0.934). Meanwhile, the value of Cronbach internal consistency coefficient for the study tool as a whole reached (0.912). Therefore, it is clear from the previous table that all the values are greater than the value $(0.70)$, and, thus, this indicates the 
consistency between the paragraphs of the study tool, its reliability, along with its credibility for conducting the statistical analysis of the study.

\section{STUDY POPULATION AND SAMPLE}

The study population is represented by all the administrative workers at Jadara University, where their number reached (130) director, including the head of department, and employees) according to the entries and records of human resources department at the university. They were chosen by the simple random sample method, which is a suitable method for the type and nature of the study as they are familiar with the information required to the study. Accordingly, the study sample constituted (97) individuals, and the researchers distributed (97) questionnaires to the members of the study sample, and (90) were retrieved, out of which (3) were non-analyzable questionnaires. So, the number of the recovered and statistically analyzed questionnaires was (87), i. e. a percentage of (89.6\%) of the total distributed questionnaires, which is statistically acceptable. Meanwhile, the study showed that the percentage of males is $(48.3 \%)$ and the majority of them ranged between 30-40 years of age, where most of them were employees. In addition, the majority had less than (15) years of experience. Table (2) summarizes the study sample.

Table (2): Demographic data for respond

\begin{tabular}{|c|c|c|c|}
\hline Variable & Category & Repetition & Percentage \\
\hline \multirow[t]{3}{*}{ Gender } & Male & 42 & 48.3 \\
\hline & Female & 45 & 51.7 \\
\hline & Total & 87 & 100 \\
\hline \multirow[t]{5}{*}{ Age } & Below 30 years old & 40 & 46 \\
\hline & $30-40$ & 30 & 34.5 \\
\hline & $40-50$ & 7 & 8 \\
\hline & Above 50 years old & 10 & 11.5 \\
\hline & Total & 87 & $100 \%$ \\
\hline \multirow[t]{5}{*}{ Experience } & Below 5 years & 34 & 39.1 \\
\hline & 5 - 10 years & 21 & 24.1 \\
\hline & 10 - 15 years & 14 & 16.1 \\
\hline & Above 15 years & 18 & 20.7 \\
\hline & Total & 87 & $100 \%$ \\
\hline \multirow[t]{4}{*}{ Position } & Manager & 13 & 14.9 \\
\hline & Section head & 1 & 1.1 \\
\hline & Employee & 73 & 84 \\
\hline & Total & 87 & $100 \%$ \\
\hline
\end{tabular}

\section{RESEARCH RESULTS \\ DESCRIPTIVE STATISTICS}

This part reviews the description of the study variables, and the arithmetic averages of the study variables were calculated for the purpose of judging the degree of approval, and determining the relative importance of each variable, where the general average of human capital in terms of the relative importance was average, which were (3.567). However, the general average of job empowerment in terms of the relative importance, the general average is $(3,452)$. Meanwhile, the general arithmetic average of chak paragraphs with knowledge in terms of the relative importance was average, where the arithmetic average was (3.522). Table No. (3) Illustrates this matter as below.

Table No. (3) The arithmetic mean of the study variables

\begin{tabular}{llll}
\hline & Variable & $\begin{array}{l}\text { Arithmetic } \\
\text { mean }\end{array}$ & $\begin{array}{l}\text { Relative } \\
\text { importance }\end{array}$ \\
\hline $\begin{array}{l}\text { Independent } \\
\text { variable }\end{array}$ & Human capital & 3,567 & Average \\
$\begin{array}{l}\text { Dependent } \\
\text { variable }\end{array}$ & Empowerment & 3,452 & Average \\
$\begin{array}{l}\text { Modified variable } \\
\text { Knowledge sharing }\end{array}$ & 3,522 & Average \\
\hline
\end{tabular}




\section{TESTING THE HYPOTHESES}

The study hypotheses seek to clarify the effect of the human capital on empowerment in the presence of sharing, as well as clarifying the effect of human capital in empowerment in the presence of knowledge sharing as a modified variable at Jadara University. To test these hypotheses, the Hierarchical Regression Analysis, which is an inferential statistical method, was used.

Table (4): Results of testing the study hypotheses

\begin{tabular}{|c|c|c|c|c|c|c|c|}
\hline \multirow{2}{*}{$\begin{array}{l}\text { Dependent } \\
\text { variable }\end{array}$} & \multirow{2}{*}{$\begin{array}{l}\text { Independent } \\
\text { variables }\end{array}$} & \multicolumn{3}{|l|}{ H1 } & \multicolumn{3}{|l|}{ H2 } \\
\hline & & B & $\begin{array}{l}\text { Computed } \\
\text { t value }\end{array}$ & Sig t & B & $\begin{array}{l}\text { Computed } \\
\text { t value }\end{array}$ & Sig t \\
\hline \multirow[t]{7}{*}{ Empowerment } & $\begin{array}{l}\text { Regression } \\
\text { constant }\end{array}$ & 0.271 & 2.544 & 0.013 & 0.041 & 0.575 & 0.567 \\
\hline & Human capital & 1.044 & 35.660 & 0.000 & 0.345 & 2.751 & 0.007 \\
\hline & $\begin{array}{l}\text { Knowledge } \\
\text { sharing }\end{array}$ & & & & 1.341 & 11.196 & 0.000 \\
\hline & $\begin{array}{l}\text { Determination } \\
\text { coefficient } R^{2}\end{array}$ & \multicolumn{3}{|l|}{0.537} & \multicolumn{3}{|l|}{0.675} \\
\hline & $\Delta \mathrm{R}^{2}$ & \multicolumn{3}{|c|}{0.537} & \multicolumn{3}{|l|}{0.138} \\
\hline & $\Delta F$ & \multicolumn{3}{|c|}{1271.633} & \multicolumn{3}{|l|}{125.342} \\
\hline & $\operatorname{Sig} \Delta \mathrm{F}$ & \multicolumn{3}{|l|}{0.000} & \multicolumn{3}{|l|}{0.000} \\
\hline
\end{tabular}

Table (4) refers to the results of the hierarchical regression that includes two models, where the results of the first model indicated a statistically significant effect (Of human capital) on (Empowerment), thus, the value of $(F=1271.633)$ and the level of significance (Sig $\Delta F=0.000$ is less than 0.05 , as the value of the coefficient of determination was $(\mathrm{R} 2=0.537)$. This indicates also that the change in the purchasing capital leads to a change in empowerment by (53.7\%). Meanwhile, the results of the second model indicated to the existence of a statistically significant effect (Of human capital) on (Empowerment) under (Knowledge sharing), so that the introduction of this variable increased the value of the coefficient of determination (R2) by (13.8\%). This percentage is statistically significant as the value of $(\Delta \mathrm{F}=125.342)$ and the level of significance is (Sig $\Delta \mathrm{F}=$ 0.000) which is less than 0.05. Besides, the value of his (B) coefficient was (1.341), and the level of significance (Sig $t=0.000$ ). This confirms the difference in the significant effect of human capital on empowerment depending on the difference in sharing knowledge.

\section{Discussion and Conclusions}

This study is aimed at identifying the modified role of knowledge sharing of the relationship between human capital and empowerment among all administrative workers at Jadara University. The results of the descriptive census of this study showed the mediating relative importance of all study variables (Human capital, knowledge sharing, and empowerment) as this result is below the required level. This is due to the university's failure to follow appropriate strategies in a number of areas, such as the university's lack of focus on attracting qualified knowledge and skills, in addition to not focusing on spreading knowledge among employees, as well as not following the university from sharing decision-making and taking decision with all employees. As for the two objectives of the study, the first objective of this study was to identify the effect of human capital on empowerment, as the results of the study found a statistically significant effect of human capital on empowerment, especially as empowerment works on trying individuals to use their talents and minds in order to achieve advantage. Competitiveness, as the bureaucracy is not suitable for knowledge workers, as they do not want to perform their work with severe control, strict rules and a formal work system. As for the second objective of this study, it is meant to identify the modified role of sharing in the know-how in the relationship between human capital and empowerment, as the results of the study found a statistically significant effect of knowledge sharing on the relationship between human capital and empowerment at Jadara University. This result was consistent with the outcome of the study (Ozbebek and Kilicarslan, 2011) which showed that empowerment correlates positively with knowledge-sharing behavior, and found out that empowered employees are more interested in sharing their knowledge. Therefore, 
empowerment is a means of equity that can lead to higher service quality and a faster response to customers. Furthermore, empowerment is often presented as a treatment for productivity and addressing various problems in organizations. Hence, empowerment is considered as a fundamental factor for modern knowledge-based institutions, as it contributes to increasing the knowledge, skills and experience of workers, which makes them more capable of creativity and innovation, as well as making them feel satisfied with their work and increases their moral and adherence to the institution in which they work, which makes empowerment a crucial issue for the success and survival of institutions continuity (Bowen and Lawler, 1994). Accordingly, the human capital and knowledge sharing have a close relationship as they are two types of competition dependent on the individual. On this basis, the first tasks of knowledge management are its responsibility to extract the tacit knowledge of human capital. Thus, this knowledge is represented in the intuitive personal experiences gained to perform a certain action, and the judgments reached. Besides, a person should practice it after the period of his performance of it has passed (Daft.2001.258). Thus, our practical recommendations for this study are formed by increasing the formal and informal relations between the employees and management at the university, and working to delegate powers by granting more independence to employees on how to perform their tasks and activities and increasing decision-making authorities for workers; this, in turn, enhances the university's ability to facilitate communication between the different units, and gives decision makers at all levels access to the best information and exchange it between managers and employees, and increase employee access to the information required and needed to perform his work. In conclusion, the university must follow all methods that lead to attracting the best skills and knowledge from workers, in order to build a human capital that has a high capacity to raise the level of organizational creativity among workers, and to benefit from their previous experiences and apply them to the university by conducting training courses on modern methods of work, in addition to conducting intensive discussion sessions to find and solve problems related to work and workers.

\section{REFERENCE}

Abdel-Hafez, Tharwat and Al-Mahdi, Yasser. (2015). The reality of practicing knowledge sharing among faculty members: An applied study on colleges of education in some Arab universities, Journal of Educational and Psychological Sciences, Volume 16, Issue 4, 480-517.

Afsar, B., Badir, Y.F., Saeed, B.B. and Hafeez, S. (2017), "Transformational and transactional leadership and employee's entrepreneurial behavior in knowledge - intensive industries", The International Journal of Human Resource Management, Vol. 28 No. 2, pp. 307-332.

Akamavi, N., \& Kimble, C., (2011), « Knowledge Sharing and Computer Supported Collaborative Work : The Role of Organizational Culture and Trust », The University of York, U.K.

Al-Ha'ar, H. (2016). The Impact of Administrative Empowerment on the Organization Performance at Jordanian Industrial Companies. Canadian Social Science, 12(2), 19-29.

AL-Hajr K.M. A.\& Obeidat, A. M. (2019) The Impact Psychological Empowerment in Achieving Job Satisfaction at the Police College, Qatar, International Journal of Business and Management, 14(9)1-14

Aljawarneh, N. M., Sokiyna, M., Obeidat, A. M., Alomari, K. A. K., Alradaideh, A. T., \& Alomari, Z. S. (2020). The Role of CRM fog computing on innovation and customer service quality: An empirical study

Al-Maani, Ahmad Ismail and Eriqan, Ahmad Yusuf and Al-Saleh, Asma Rashad and Jaradat, Muhammad Saud, "Contemporary Administrative Issues", First Edition, Wael Publishing House, Amman, 2010

AL-Ma'ani, Ahmed I., Jaradat, Nasser, ( 2010 ), Impact Of Human Capital on The Organization Performance, Interdisciplinary Journal of contemporary Research in Business, Vol. 2, No. 4,pp.63-73.

Al-Nima, Adel Zakir and Suleiman, Sarhan, "2012 The role of empowering workers in supporting the goals of continuous improvement: A field study in the General Company for Medicines and Medical Supplies in Nineveh", Al-Rafidain Development, University of Mosul, College of Administration and Economics, Volume 34, Issue 108,

Al-Qassas, Medi (2008), "The Environment for Human Capital Investment, a Field Study on an Egyptian Village", The Third Scientific Study, "Contemporary Environmental Issues and Community Participation", South Valley University, 13-15 November, Luxor, Egypt.

Al-Qudah, S., Obeidat, A. M., \& Shrouf, H. (2020). The impact of strategic human resources planning on the organizational performance of public shareholding companies in Jordan. Problems and Perspectives in Management, 18(1), 219. 
Al-Rumaihi, Tahani (2011), Employment Empowerment and its Impact on Organizational Confidence among Government Health Centers Workers in the Kingdom of Bahrain, Unpublished Master Thesis, Delmon University, Bahrain.

Al-Sijari, Abdul Razzaq Yaqoub Yousef (2012), The Effect of Using Information Technology on the Creative Behavior of Workers in Commercial Financial Institutions in Kuwait, Unpublished Master Thesis, Delmon University, Bahrain.

Al-Tamimi, Iyad Fadel (2114), Creative Behavior and its impact on competitive advantage, Insights Magazine, Mutah University, Volume 8, Issue

Al-Tanboor, Ramez. (2007). Human Capital as a Management Strategy, The Second Scientific Conference, AlIsra University, Jordan.

Bartol, K. M \& Srivastava, A. (2002). Encouraging knowledge sharing: the role of organizational reward systems, journal of leadership and organization studies, 9(1) , $64-76$.

Bowen, David E. and Lawler, Edward (1994), the Employee Empowerment approach to service, center for effective organization Publication, Marshall School of Business, university of southern California, Los Angelo's.

Buta, S. (2015). Human capital theory and human resource management. implications in development of knowledge management strategies. Eco forum Journal, 4(1), 22.

Carter, M. (2009). Visible learning: A synthesis of over 800 meta-analyses relating to achievement.

Chau, T., Maurer, F., \& Melnik, G., (2003), "Knowledge Sharing: Agile Methods V.S. Tayloristic Methods", University of Calgary, Canada

Chen, I.Y.L., Chen, N.S., \& Kinshuk, (2012), " Examining the Factors Influencing Participants' Knowledge Sharing Behavior in Virtual Learning Communities », Educational Technology \& Society, Vol. 12, No. 1.

Coff R and Kryscynski D (2011) Drilling for micro-foundations of human capital-based competitive advantages. Journal of Management 37: 1429-1443.

Crawford, C.B., (2011), « Transformational Leadership, Innovation and Knowledge Management : Empirical Findings and Emergent Conclusions », Knowledge Management \& Leadership

Daft, R. L., (2001), "Organization theory and design", 7th Edition, South - Western College Publishing, Ohio, USA

Delery JE and Roumpi D (2017) Strategic human resource management, human capital and competitive advantage: Is the field going in circles? Human Resource Management Journal 27: 1-21.

Derry, Al-Kiswani, Zahid, Saadeh, "Managing the Human Element in Modern Business Organizations", First Edition, House of Kunuz Al-Ma'rifah Scientific Publishing and Distribution, Amman, 2008

Drucker, P. F. (1993). The rise of the knowledge society. The Wilson Quarterly, 17(2), 52-72.

Fernandez, Sergio and Moldogaziev, Tima (2011) , A Causal Model of the Empowerment Process: Exploring the Links between Empowerment Practices, 12National Public Management Research Conference, Maxwell School, Syracuse University, New York

Fitzenz, Jac (2000): The ROI of Human Capital: Measuring The Economic Value of Employee

Griffin, R. W., \& Moorhead, G. (2014). Managing People in Organization. South-Western: USA.

Haitham Ali Hijazi, Knowledge Management A Theoretical Introduction, Al-Ahlia Publishing and Distribution, First Arab Edition, Amman-Jordan, 2005, p.61

Hamshari, Omar (2013). Knowledge Management: The Road to Excellence and Entrepreneurship, Dar Al-Safa for Publishing and Distribution, Amman, Jordan.

Hassan, Hussain Ajlan (2008). Strategies for knowledge management in business organizations. Oman: Ithraa for Publishing and Distribution.

Hegazy, Haitham, "Knowledge Management A Theoretical Approach", First Edition, Eligibility for Publishing and Distribution, 2005.

Henkin, A. (2011). Teacher-Principal relationships: Exploring linkage between empowerment and interpersonal trust, Journal of Educational Administrative, P: 260

Herzberg, F. Mausner, B. \& Snyderman, B. (2013). The Motivation to Work, New York Wiley, P:51

Honold, L. (2011). A review of the literature on employee empowerment, Empowerment in Organizations, P: 202.

Jalib, Ihsan Dahsh and Al-Hussaini, Kamal Kazem Ahar, "Empowerment and Integration Administration", First edition, Safaa House for Publishing and Distribution, Amman, 2013 
Kirkman, B. L., Rosen, B., Tesluk, P. E., \& Gibson, C. B. (2004). The impact of team empowerment on virtual team performance: The moderating role of face-to-face interaction. Academy of management journal, 47(2), 175-192.

Lee, J. (2001). The impact of knowledge sharing, Organizational capability and partnership quality on IS outsourcing success, information \& Management, 38 (5), 323 - 335.

Mahfodh, A. B. S. B., \& Obeidat, A. M. (2020). Knowledge Sharing Tools and their Impact on Enhancing Organizational Performance. International Journal of Academic Research in Business and Social Sciences. 10(9), 91-112.

Malhotra, Y. (2003), Measuring Knowledge assets of a Nation: Knowledge systems for Development, United Nations Advisory Meeting of the Department of Economic \& Social Affairs: Division of Public Administration \& Development Management, New York 4-5 September

Melhem, Yahya (2006), Empowerment: A Contemporary Management Concept, Arab Administrative Development Organization, Jordan.

Moke, E. (2012), Relationships between Organizational Climate and Empowerment of Nurses in Hong Kong. Nurses Review, 10(3), 1-19.

Naeem Ibrahim Al-Zahir, Knowledge Management, a wall for the book of the world for publishing and distribution, first edition, Amman, Jordan, 2009-1429, pp. 9697.

Obeidat, A. (2019). IT Adaption with Knowledge Conversion Process (SECI)?. Management Science Letters, 9(13), 2241-2252.

Obeidat, A. M., \& Otibi, G. A. (2015). The impact of knowledge sharing tools on levels of organizational learning (Field Study on Jordanian Commercial Banks). Australian Journal of Basic and Applied Sciences, 9(5), 253-267.

Obeidat, A. M., Abualoush, S. H., Irtaimeh, H. J., Khaddam, A. A., \& Bataineh, K. A. (2018). The role of organizational culture in enhancing the human capital applied study on the social security corporation. International Journal of Learning and Intellectual Capital, 15(3), 258-276.

Ozbebek, A. and Kilicarslan, T.E. (2011), “Empowered employees' knowledge sharing behavior”, International Journal of Business and Management Studies, Vol. 3 No. 2, pp. 69-76.

Ozbebek, A., \& Toplu, E.K., (2011), “Empowered Employees' Knowledge Sharing”, International of Business and Management Studies, Vol. 3, No. 2.

Ployhart RE (2006) Staffing in the 21st century: New challenges and strategic opportunities. Journal of Management 32: 868-897.

Saffar, N., \& Obeidat, A. (2020). The effect of total quality management practices on employee performance: The moderating role of knowledge sharing. Management Science Letters, 10(1), 77-90.

Schermerhorn, Jr., R. R., Hunt, J. G., \& Osborn, R. N. (2001). Organizational behavior, 7th Edition, New York: Wiley.

Shabir, Muhammad. (2015). The Role of Business Intelligence Systems in Developing Human Capital in the Palestinian Banking Sector - Case Study (Bank of Palestine), Unpublished Master Thesis, Faculty of Commerce, Islamic University, Gaza.

Shrouf, H., Al-Qudah, S., Khawaldeh, K., Obeidat, A., \& Rawashdeh, A. (2020). A study on relationship between human resources and strategic performance: The mediating role of productivity. Management Science Letters, 10(13), 3189-3196.

Spector, B. (2011). Taking Change \& Letting go, New York, The Free Press, P:44

Sternberg, Robert J. and Grigorenko, Elena L. "Successful Intelligence in the Classroom", College of Education, the Ohio State University, Vol. 43. No. 4, 2004.

Tripathi, D., Priyadarshi, P., Kumar, P., \& Kumar, S. (2020). Does servant leadership affect work role performance via knowledge sharing and psychological empowerment? VINE Journal of Information and Knowledge Management Systems.

\section{APPENDEX (1)}

\begin{tabular}{|c|l|l|l|}
\hline No. & Paragraph & Mean & SD \\
\hline First field: & Human Capital & $\mathbf{3 . 5 6 7}$ & \\
\hline 1. & $\begin{array}{l}\text { The university is keen to provide knowledge for its } \\
\text { employees. }\end{array}$ & 3.690 & 0.840 \\
\hline 2. & The university is interested in bringing in employees & 3.609 & 0.907 \\
\hline
\end{tabular}




\begin{tabular}{|c|c|c|c|}
\hline & who possess the skills and knowledge. & & \\
\hline 3. & $\begin{array}{l}\text { The university relies on the interview in the } \\
\text { recruitment process. }\end{array}$ & 3.368 & 1.132 \\
\hline 4. & $\begin{array}{l}\text { The university encourages the establishment of } \\
\text { training courses for its employees. }\end{array}$ & 3.333 & 1.188 \\
\hline 5. & $\begin{array}{l}\text { My work provides me with opportunities to learn and } \\
\text { gain new experiences in the field of work. }\end{array}$ & 3.770 & 0.961 \\
\hline 6. & Get help in all of its forms when needed. & 3.575 & 0.996 \\
\hline 7. & $\begin{array}{l}\text { The university is keen to make its mission and vision } \\
\text { clear to employees. }\end{array}$ & 3.621 & 0.955 \\
\hline \multicolumn{2}{|c|}{ Second field: Knowledge Sharing } & 3.522 & \\
\hline 8. & $\begin{array}{l}\text { The university contributes to spreading knowledge } \\
\text { among employees. }\end{array}$ & 3.379 & 0.931 \\
\hline 9. & The university is interested in holding seminars. & 3.115 & 1.039 \\
\hline 10. & $\begin{array}{l}\text { The university holds special courses in order to } \\
\text { realize knowledge. }\end{array}$ & 3.103 & 1.131 \\
\hline 11. & $\begin{array}{l}\text { The university contributes to the generation of } \\
\text { knowledge among the employees. }\end{array}$ & 3.276 & 1.019 \\
\hline 12. & $\begin{array}{l}\text { The university contributes to developing methods } \\
\text { and methods of obtaining knowledge. }\end{array}$ & 3.356 & 1.034 \\
\hline 13. & The university encourages collaborative work & 3.644 & 0.976 \\
\hline 14. & $\begin{array}{l}\text { The University deals with the expertise and skills of } \\
\text { employees as an important part of our knowledge } \\
\text { assets. }\end{array}$ & 3.540 & 0.998 \\
\hline \multicolumn{2}{|c|}{ Third field: Empowerment } & 3.452 & \\
\hline 15. & $\begin{array}{l}\text { The university evaluates the workers in a proper } \\
\text { manner. }\end{array}$ & 3.448 & 0.985 \\
\hline 16. & $\begin{array}{l}\text { The university encourages those working in the } \\
\text { generation of innovation and creativity. }\end{array}$ & 3.322 & 0.946 \\
\hline 17. & The university encourages teamwork. & 3.460 & 0.986 \\
\hline 18. & $\begin{array}{l}\text { The university contributes staff to express their } \\
\text { opinions }\end{array}$ & 3.195 & 0.963 \\
\hline 19. & The university urges the staff to hold seminars & 3.230 & 0.985 \\
\hline 20. & $\begin{array}{llll}\begin{array}{l}\text { The university offers } \\
\text { outstanding employees. }\end{array} & \text { financial rewards } & \text { for } \\
\end{array}$ & 3.115 & 1.233 \\
\hline 21. & $\begin{array}{l}\text { The university is based on sharing decisions with its } \\
\text { employees }\end{array}$ & 2.828 & 1.081 \\
\hline 22. & $\begin{array}{l}\text { I feel that I am in the right place for my academic } \\
\text { qualifications and work experience. }\end{array}$ & 3.345 & 1.180 \\
\hline 23. & $\begin{array}{l}\text { Achieving the university's goals is one of my top } \\
\text { priorities. }\end{array}$ & 3.747 & 1.025 \\
\hline
\end{tabular}

